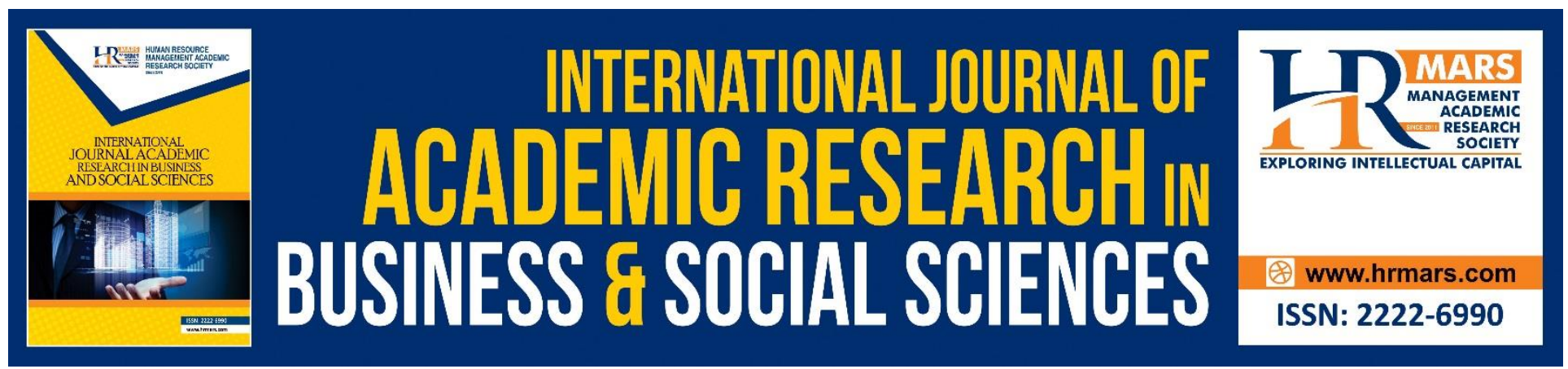

\title{
An Appraisal of Majallat al-Ahkam al-Adliyyahr. A Legal Code of Islamic Civil Transactions by the Ottoman
}

\author{
Md. Habibur Rahman, Noor Mohammad Osmani
}

To Link this Article: http://dx.doi.org/10.6007/IJARBSS/v8-i9/4703

DOI: $\quad 10.6007 /$ IJARBSS/v8-i9/4703

Received: 02 August 2018, Revised: 23 August 2018, Accepted: 29 Sept 2018

Published Online: 15 October 2018

In-Text Citation: (Rahman \& Osmani, 2018)

To Cite this Article: Rahman, M. H., \& Osmani, N. M. (2018). An Appraisal of Majallat al-Ahkam al-Adliyyah: A Legal Code of Islamic Civil Transactions by the Ottoman. International Journal of Academic Research in Business and Social Sciences, 8(9), 1381-1393.

Copyright: (C) 2018 The Author(s)

Published by Human Resource Management Academic Research Society (www.hrmars.com)

This article is published under the Creative Commons Attribution (CC BY 4.0) license. Anyone may reproduce, distribute, translate and create derivative works of this article (for both commercial and non-commercial purposes), subject to full attribution to the original publication and authors. The full terms of this license may be seen at: http://creativecommons.org/licences/by/4.0/legalcode

Vol. 8, No. 9, September 2018, Pg. 1381 - 1393

Full Terms \& Conditions of access and use can be found at http://hrmars.com/index.php/pages/detail/publication-ethics 


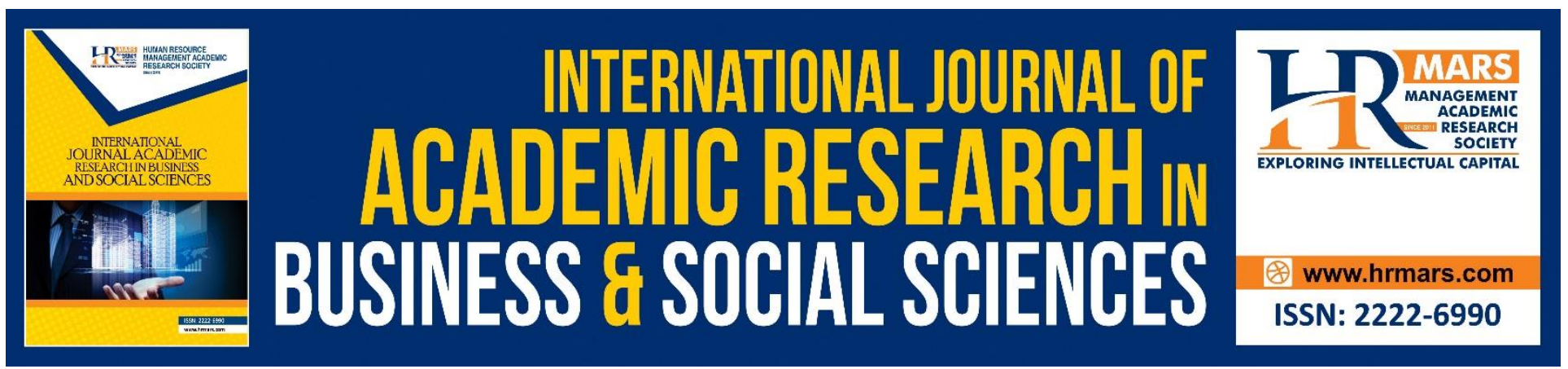

\title{
An Appraisal of Majallat al-Ahkam al-Adliyyahr. A Legal Code of Islamic Civil Transactions by the Ottoman
}

\author{
Md. Habibur Rahman \\ (Corresponding Author) \\ Faculty of Economics and Management Sciences, Sultan Zainal Abidin University (UniSZA) \\ Email: habiburrahman@unisza.edu.my \\ Noor Mohammad Osmani \\ Kulliyyah of Islamic Revealed Knowledge and Human Sciences, International Islamic University \\ Malaysia (IIUM) \\ Email: abusajid@iium.edu.my
}

\begin{abstract}
The Majallat al-Ahkam al-Adliyyah, known as the Mejelle, is a legal code of Islamic civil transactions drafted under the auspices of the Ottoman. This study intends to introduce the Mejelle and to evaluate the codification attempt made by the Mejelle. Employing analytical and critical methods the study finds out that in codification of Islamic civil transactions the attempt of the Mejelle is comparatively more successful and it explicitly distinguishes between the method of being reference for learning and reference for judiciary. The study demonstrates that generally the Mejelle consents to the preponderant views of Hanafi School, excluding few cases in which it conforms to minority Hanafi views considering public wellbeing and needs of the time. Nevertheless, the compilation process of the Mejelle complies with the principles of giving preponderance of the Hanafi School of Islamic law.
\end{abstract}

Keywords: The Mejelle, Codification, Islamic Civil Transactions, Majallat al-Ahkam al-Adliyyah, The Ottoman

\section{Introduction}

The Majallat al-Ahkam al-Adliyyah known as The 'Mejelle' was composed between 1869 CE and 1876 CE as part of the legislative process of the tanzimat (the period of reorganization and reformation of the Ottoman Empire) initiated by the Ottoman Caliphate. The Mejelle represents an attempt to codify that part of the Hanafi figh which deals with civil transactions (mu'amalat). The codification was the work of a Commission of Jurists, headed by Ahmad Djevdet Pasha, the Minister of Justice of Ottoman Caliphate (Rahman, 1967). The Mejelle contains 1851 articles that encompass legal (shar'i) provisions 
for the various civil transactions, such as sale, rent, guarantee, agency, etc. with compact pattern that organized the fighi issues which were dispersed and scattered. Hence, the Mejelle actualized a great legislative task, and bridged a big gap in the judiciary and the lawful transactions that proved the greatness and prestige of Islamic jurisprudence in the face of Western laws and established its superiority on this. In fact, the Mejelle is considered as a proof of the flexibility of Islamic law in a sense that it can accommodate the changes of time. Thus, it actualized a significant achievement for Islamic jurisprudence and its reformation which rejoices the hearts of scholars and Muslims in general.

Throughout the history there were numerous efforts made to codify the Islamic law. It started notably by the efforts of Ibn al-Muqaffa, then the efforts of two Caliphs of the Abbasid Caliphate, Abu Ja'far Mansur and Harun al-Rashid, and the efforts of Sultan Muhammad Aurangzeb Alamghir of the Indian subcontinent, followed by the comparatively successful efforts made by the Ottoman Caliphate. Thereafter, the stream of the codification of Islamic law continues, such as through the efforts of Qadri Basha of Egypt, Muhammad Amir of Libya, efforts made to codify the family law of Egypt and Syria, efforts of Abd Allah al-Qari, etc. are notable in this regard. The experiences and activities of the fiqhi councils over the world are also being considered a significant improvement in the process of the codification of Islamic law. The contemporary development of the standardization of Islamic provisions made by the Accounting and Auditing Organization for Islamic Financial Institutions (AAOIFI) of Bahrain, Islamic Financial Services Board (IFSB) of Malaysia, and the like could be considered a big step forward for the codification of Islamic law.

\section{Problem Statement}

There is an argument says that the objective of compiling the Mejelle was to secularize the Shari'ah law and thus it was accomplished accordingly. Supporting such argument it is claimed that in the process of compiling the Mejelle, the methods and principles of jurisprudence (usul al-fiqh) were not followed. Also, it is argued that its compilation was not grounded on scholarly debates and discussions, rather on the Ottoman decrees instead. In addition, students and researchers from other Schools are reluctant to rely on articles of the Mejelle as they were composed based on the Hanafi School without any appendix which usually encompasses the sources, discussion and details of the rulings. As a result, presently the Mejelle does not have the effective role as it was previously. Furthermore, it was accomplished during a specific regime of Ottoman Caliphate while we are now in different era with different circumstances, systems, lifestyles and so forth. Thus, Zarqa (1998) says that if the articles of Mejelle were not formed on the Hanafi School only, rather were relied on various discretionary (ijtihadi) views which fulfill needs of the time, there would not have any reason to modify the Mejelle soon after its issuance. Hence, this study intends to make a preliminary analysis of the Mejelle along with an appraisal of its strength and shortcomings.

\section{The Majallat al-Ahkam al-Adliyyah}

Actually the word 'Majallah' is derived from the root word 'jalal' which denotes the sense of grandness, magnificence, abundance, exaltation, etc. Lexically, Majallah means the book, sheet, notebook, booklet, etc. Nowadays Majallah refers to the magazine, journal and newspaper that is published in booklet shape, etc. (al-Munjid, 2002). Actually, Majallah means the book and booklet 
which gathers the unique and newly acquired issues of scholarship (al-Mu'jam al-Wasit). The word 'Majalla' also means the knowledge (ilm) and wisdom (figh) (Husayni, 1993).

Some lexicologists opine that the word 'Majallah' has been arabicized from the Hebrew while others opine that it is originally an Arabic word (Ibn Manzur, 1990). Abu Ubayd says that generally in Arabic each book or booklet is called Majallah (Husayni). Ibn al-A'rabi says: I asked a Bedouin while I am holding a booklet, "What is Majallah?" The Bedouin replied, "That is in your hand" (Husayni). However, in classical Arabic, Majallah refers particularly to the booklet that contains the wisdom and insightful thoughts. Ibn Sayyid says that Majallah is the booklet of wisdom and intellect (Ibn Manzur). Nevertheless, relating to the story of Suwayd ibn Samit, he came to the Prophet (pbuh) and told him: "Perhaps what you have is the same as that I have". The Prophet said: "What do you have?" He said: "Majallah of Luqman", referring to a book which contains the wisdom of Luqman (al-Bayhaqi, 2002; Husayni; Ibn Manzur). So, Majallah refers to the book or booklet which contains the wisdom and insightful thoughts. In the classical Arabic poetry, the famed poet al-Nabighah al-Zubyani (d. 604 CE, was one of the poet laureates in the pre-Islamic period) had used the word Majallah for the divine books of Bani Ghassan, which were considered among them as the books of wisdom and insight (Fayyumi, 1323AH; Husayni; Ibn Manzur). Furthermore, when Ibn Abbas recites the poetry of Umayyah he used to say: "Majallat Ibn Abi al-Salt" (Zamakhshari, 1998; Husayni). Additionally, referring to the books of wisdom, Anas said: "Ulqiya ilayna majallun", majallun is the plural form of majallah, i.e. we were given several books of wisdom (Ibn Manzur). So, it is found that the word 'Majallah' refers to the book, booklet, notebook, etc. However, it may not refer to an ordinary book, but rather it refers to a book that contains something significant and leading, which could be considered as wisdom, insight, fundamentals, principles, standards, regulations, code, manual, etc.

Moreover, in the title "Majallat al-Ahkam al-Adliyyah" the word 'al-adliyyah' is derived from the verbal noun 'adl' which means rectify, reform, amend, etc. The word adl refers also to law and justice which is the opposite of tyranny and oppression (al-Munjud). So, the "Majallat al-Ahkam alAdliyyah" could be translated as the legal code or manual. Since the Mejelle of the Ottoman is drafted based on the fiqhi provisions, it could be translated as the Shari'ah code or Shari'ah manual.

\section{Emergence of the Mejelle and Its Reason}

A. As the official committee stated in the report submitted to the Prime Minister Ali Basha in 1286 $\mathrm{AH}$, the direct and explicit motive for compilation of the Mejelle was that, since the commercial transactions expanded and communication with outside world increased, all these required a number of exemptions from the general ruling that comprised the so-called Civil Law. Thus, due to this expansion, two separate laws, one for commerce and another for penalties were set, and courts for commerce and court for penalties were established. The cases which were not mentioned in the commercial law, as well as the civil rights related to crimes were referred to as the original law, i.e. the fiqhi provisions which were adequate for corresponding to the above needs. However, a new problem emerged. The judges of the Nizamiyyah (regular) Courts and the Court of Cassation had no knowledge on the reasonably exhaustive (figh) jurisprudence and its provisions, particularly the Hanafi figh. Moreover, there were many jurisprudential opinions within a particular School (mazhab) of law, and the differences among the scholars and jurists made it extremely difficult to distinguish between sound and weak opinions. Then, there was also 
the difference caused by the changes of time, custom and culture among the fuqaha of the earlier and later eras. Thus, it becomes very difficult to distinguish between the time-based and evidence-based differences, for it required precise jurisprudential perspective. This, consequently, necessitated to have a book on jurisprudential transactions that would be accurate, easy to comprehend, free from the controversies of the differences of opinions, and easily referable to all. Therefore, the board, commissioned by the royal decree of the department of law, met with the goal of drafting a book (Majallah) comprised the most common issues and problems, from the jurisprudential civil transactions, through compiling the comparatively sound opinions thereof based on the Hanafi School. It was named "Majallat al-Ahkam al-Adliyyah", and was introduced with the Islamic legal maxims that owe to their integral benefit while endorsing the fiqhi issues (al-Majallah, 1203AH; Zarqa).

B. The provisions of Islamic law are scattered in the fiqhi books of all the Schools of law. Numerous provisions are discussed discursively under different chapters and sections. Moreover, the fiqhi books are also different in terms of encompassing the provisions and legal opinions, such as some are elaborate and detailed while others are brief and succinct. Also, some provisions are available in one book while not being available in another book. Sometimes the provisions of one book are in conflict and disagreement with that of other books. Also, the fiqhi books are different in terms of their language, pattern, expression and so forth. Thus, acquaintance with the fiqhi provisions and reaching an utmost level is a challenging task. Hence, the study of these kinds of books to get fighi provisions, to derive accurate and exact legal rulings, to differentiate between sound and weak opinions, to give preponderance to the strongest opinion etc. require talent, long experience, and well-acquaintance with the fiqhi rulings and provisions, which is really difficult for most individuals. So, it is now extremely needed to find a way to ease the review and study of reliable and sound fiqhi provisions without wading into the depth of the classical fiqhi books (Qubbaj, 2008; Zarqa).

C. The Ottoman state officially ascribed to the Hanafi School. This school has a big number of scholars and jurists in different levels, and also the fiqhi differences and disagreements are abundant in this School. Moreover, no such revision or review happened in this School as it happened in Shafi'i School. Rather, the provisions, rulings and discussions are scattered and dispersed. Hence, distinguishing the sound stand from these different and various issues and opinions, as well as applying that to incidents and cases is quite difficult and tough. A researcher in Hanafi School will find difficulty in understanding its chapters, sections, indexes and so forth, unlike the Shafi'i School which has been reviewed and rectified by scholars like al-Rafi'i, alNawawi and others, which eased the job of research and ijtihad in this School. So, it was difficult if not quite impossible for the judges who were not experts in fiqh to dive into the depth of Hanafi School to derive necessary rulings and judgments. Hence, it became vital for the state to issue a legal code which could be easily referred to and comprehended by judges and jurists of all levels (Qubbaj \& Zarqa).

D. Changes in situations, conditions and culture have had impacts on many Shari'ah rulings resulting by ijtihad. This is because the Shari'ah ruling derived based on people's customs and traditions would change according to the change in customs and traditions of the people. For instance, in the past the option of inspection (khiyar al-ru'yah) expires after the scrutiny of one of the rooms 
of the house, as it was the custom that people were familiar with. On this ground, jurists had the opinion that the option of inspection would be terminated after checking one of the rooms of the house. However, later on, as custom changed in the construction of houses, along with their internal design, and so on, jurists essentially revised the previous decision, and opined that the right of inspection would not be expired after the assessment of one of the rooms of the house. Instead, all the rooms of the house, as well as its internal pattern needed to be scrutinized (Qubbaj \& Zarqa). So, the attempt to produce the Mejelle could be called the typical response initiated by the Ottoman state to address the changes in the customs and traditions of the people. This was especially because the Hanafi School considers customs, traditions, etc. important in passing the judgments.

E. In order to conclude the judgment, it was not possible for the Ottoman authorities to appoint in the Nizamiyyah courts those who were able to review the fiqhi books when it is necessary. This was because the number of qualified judges, who were experts in fiqh was limited. The reviewing of the fiqhi books requires special expertise and thus is the job of scholars of fiqh and not typical judges. Hence, having this kind of judge for all the Shari'ah courts of the Ottoman state was not essentially possible. Because of this the Ottoman state needed a legal code that would ease the job of the judges to pass the rulings, including rulings regarding Shari'ah matters. Moreover, having such a legal code also had become essential to uphold the fame of the judges and judiciary. Also, it contributed to reducing the conflict and disagreement in the judgments that were passed all over the state. Additionally, the Ottoman authority felt that there was inherent danger in the conventional legal code that threatened them through its attractive form and compact harmonization. Hence, the acquaintance of the Ottoman authority with the Western systems, and the declining power of the state made them think to protect themselves from the danger of the western conventional legal system, especially when western colonization started to threaten the state. Therefore, the Ottoman state made efforts to produce such a legal code which resembles the Western law in form, while in substance it is to be derived from Islamic jurisprudence (Qattan, 1982).

\section{General Description of the Mejelle (Features and Shortcomings) Features of the Mejelle:}

As mentioned above, the Mejelle literally means a written book and refers to a civil code drafted by the Ottoman state pursuant to the Hanafi School between 1869 and 1876, containing 1851 legal articles. In fact, the Mejelle was the first official experience for a civil code which was completely derived from Islamic jurisprudence. Before that, there were no such written form of general civil law for the Ottoman state and its subordinates of Arab countries such as Syria, Palestine, Iraq, and so forth. Rather, the judiciary systems thereof were based on the preponderant stands of the scholars of Hanafi Schools, which was the School of the state. Nonetheless, three sections of fiqh have not been included in the Mejelle, such as the rituals (ibadat), personal statutes ranging from marriage to inheritance and what lies between them (ahwal shakhșiyyah), and rulings pertaining to penalties (uqubat) as they were left for the Penal Code which was issued in $1274 \mathrm{AH}$ (Zarqa, Cigdem). 
In the period of drafting, the Mejelle started with the demonstration of 99 legal maxims, where each or a group of them dominated a big area of figh depending on the theme of the maxim. For instance, the maxim "Things are judged by their intentions", lays the foundation of the differences in judicial rulings according to the differences in the good and bad intentions of actions and dispositions. Likewise, the maxim "Contracts are considered in the light of objectives and meanings" lays the foundation of observing the intentions of the contractors in interpreting the contracts. This section ends with the maxims of organizing evidence that are related to confessions and evidences and the limits of their usage. These maxims, nevertheless, have a great role in developing the jurisprudential talent as well as the understanding of legal and judicial concepts, even though the report of the Mejelle warns against the complete reliance of the judges on the maxims without referring to other texts. This is because, in most cases, every maxim has exceptions which are usually applicable to another different maxim (Zarqa).

The most important feature of the Mejelle is its compilation of jurisprudence that was used as the main reference in the earlier Ottoman period. The Mejelle had unprecedentedly introduced the difference between the commentarial approach of figh and the commanding approach of legalization. Hence, the Mejelle drafted the figh into the form of a judicial reference, modeled on modern laws in terms of sequencing, numbering, the method of expressing commands, simplicity of wordings, and selecting one opinion to be implemented without mentioning the evidences, discussions and differences found aplenty in the figh books. The content of such fiqh books is commentarial fiqh and do not act as a judicial reference even though they serve as a huge legal treasure that help enlighten the minds of law students and researchers (Zarqa, Badawi \& Bugha).

\section{Shortcomings of the Mejelle:}

As to the shortcomings of the Mejelle, scholars have discussed this from several dimensions such as the layout of legal explanation, the structure, and the theme or substance of the book. Pertinent to the planning or layout, the provisions of the Mejelle contain lengthy practical examples as elucidation for the principles and rulings. They also contain obvious definitions such as defining the seller as the one who sells, and the buyer as the one who buys. All these do not conform to the modern method of codification which dictates that the legal wording has to be marked in a commanding nature, by considering the fact that the law is commanding and not teaching. Thus, the scope of practical explanations and teaching is the commentaries (of fiqh) and not the texts of the law (Zarqa \& Bugha). This shortcoming however, as Zarqa mentioned, is covered by the fact that the Mejelle was developed to fulfill the needs of regular employees and judges, who were mostly Turkish and had no legal education background. Therefore, the environment at that time called for such an explanatory work.

As to the defect pertaining to the structure and form of the Mejelle is that it contains rulings which are known today as the law of judicial procedure or formal rulings. However, the civil law in its modern form does not include except substantive rulings and not the formal rulings. This is because the figh books contain chapters of formal rulings which overlap with the chapters on substantive rulings. Thus, the Mejelle, being derived from jurisprudential sources, has followed the same trend, even though it does not conform to the essence of codification. However, though it is an issue of separating or combining the portions of the law, this separation or combination does not affect the practical results. It therefore comes under the modern perception of classifying the law (Zarqa). 
Another shortcoming, the most important, is related to the substance and subject matter, whereby it is noted that the Mejelle has adopted only one School, namely the Hanafi School. There is no doubt that a single School of law, no matter how wide the scope of its principles and branches, or its theories and extrapolations, will not be able to fulfill the needs of the people in their evolving legislative needs. The wide scope of the capabilities of the fiqh will be better represented in the collection of discretionary judgments (ijtihadat) of all Schools and scholars, and not in just a single School. It was necessary therefore, that the Mejelle ought to be derived from all the Schools of Islamic law; including the best of what each of them had to offer and the most congruent with the interests of time and needs of the society. The society referred to here is one that was poised to be witness to a huge development in the fields of economy and dealings as a result of economic, political and cultural communication between the East and the modern West. As a result, the publication of the Mejelle was not useful for long, for it was not sufficient enough to fulfill the contemporary needs arising from the modern economic trends in trade, employment, and other sections of production. These in turn called for remedies supported by consecutive laws, some of which abrogated some sections of the Mejelle. So, if the committee of the Mejelle had based their compilation on what was deemed more useful and fulfilling and had referred to the discretionary views of all Schools and scholars of Islamic law instead of just the Hanafi School, there would have been no need to make amendments and adjustments thereof. The various jurisprudential schools as a whole are sufficient to fulfill the needs of time, and therefore, the reliance of the Mejelle on them could have made it very stable and steady. Nevertheless, the committee of the Mejelle has to be excused, as Zarqa mentioned, since the circumstances at that time did not permit this step to be taken. This is because there was strong affiliation to the Hanafi School among the high officials of the Ottoman state, and the Mejelle was drafted to serve their purpose. This affiliation did not give the room for other Schools of Islamic law, to get benefited from their thoughts, opinions and discretionary judgments, although in some cases they would have been better to consider than what was available in the Hanafi School (Zarqa).

\section{Method Applied in the Mejelle to Deal with the Hanafi School}

It is known that in $1286 \mathrm{AH}$ the authorized commission to draft the Mejelle developed the articles which are chosen from the section of civil transactions (mu'amalat) of the Hanafi School that the state relied on. The committee arranged the contents of the book in the familiar format of jurisprudential books and chapters, but distinguished the rulings in the form of legal articles with numbers like modern laws for easy reference. However, the Mejelle also adopted some weak opinions of the Hanafi School pursuant to the interests of that time. Nevertheless, the authors discuss here the methods applied by the committee to deal with the application of the Hanafi School of law.

\section{Observing the Fundamentals of giving Preponderance (qawa'id al-tarjih) in Hanafi School:}

The principle followed by Imam Abu Hanifah in the establishment of his legal School can be best understood in his following words, I will take the ruling from the Book of Allah if I find so, if I do not find there I will take from the Sunnah of the Messenger of Allah, which are sound, authentic and narrated by reliable relevant personalities. If I do find neither in the Qur'an, nor in the Sunnah, I will 
take from the Companions whatever I want and I skip whatever I want, yet I will not go beyond their opinions. Then if it reaches at Ibrahim, Sha'bi, Hasan, Ibn Sirin, Sa'id ibn Musayyab and the like, I will do ijtihad as they did (Qubbaj). In fact, the basis of this principle is the narration of Mu'az ibn Jabal where he said to the Prophet (pbuh) that first he will make judgment by the Qur'an, then by the Sunnah, and then he will do his own ijtihad if needed (Abu Daud, 25:3592; Tirmizi, 13:1327). So, this is the beginning of this School, which is founded on the principles and fundamentals surrounded by the fence of the Shari'ah. Due to the availability of numerous scholars in this School, opinions and fatwas are abundant. Therefore, the experts and scholars of this School had to come up with some rules and principles to deal with these abundant views and instances of discretionary judgments (ijtihadat) by conducting inductive and profound research within the School. Some of these principles, which were applied by the committee of the Mejelle in the process of drafting it, have been discussed below.

1. If the case is reported in Zahir al-Riwayah (the primary and reliable references of Hanafi School) without any disagreement among the scholars of the School, it will be considered the stand of the School, though the scholars did not proclaim its soundness. However, any deviation from Zahir alRiwayah to the stand of the later scholars is allowed if there is a necessity for that, since it is known that if Imam Abu Hanifah had been alive in their period he would have opined the same (Hawwa, 2002). However, if Imam Abu Hanifah and his two prominent disciples (sahiban) agree on any opinion then departing from that opinion is not allowed except for exigency (Ibn Abidin \& Ali, n.d.)

2. If the case is reported in Zahir al-Riwayah, but is debatable among the scholars, then it should be checked whether Imam Abu Hanifah concurs with any of his disciples. If he does so, then their opinion will be preferred to the stand of the one who disagrees with them, provided that the later scholars of the School do not give preponderance to any other opinion contrary to this (Hawwa).

3. If the case is recorded in Zahir al-Riwayah, and is disputed among the scholars in a way that Abu Hanifah makes one opinion and his two disciples dissent from his opinion, in this case it should be seen whether all of them have a different opinion from each other or not. If it is so, then the opinion of Abu Hanifah would be preferred. However, if the two disciples agree on a stand which is contrary to the stand of Abu Hanifah, so that it becomes such that he is on one side and they are on the other side, and the disagreement is due to the difference of time, era and situation, then the stand of his disciples will be taken into account since the situations of the people vary from time to time. For instance, the case of sharecropping (muzara'ah), in which the opinion of the two disciples is taken because of the consensus of later scholars on its validity. Nevertheless, if the disagreement is not due to the difference of time and period, then the stand of Abu Hanifah will be preferred, as Abd Allah ibn al-Mubarak advocates. There is also another opinion which states that in this case the mufti would be given an option to prefer whatever he deems appropriate and relevant. However, a third opinion states that if the mufti is capable of performing the discretion (ijtihad) then he would be given the option to opine what he deems perfect, otherwise fatwa would be given in accordance with the stand of the Imam. However, this principle is subject to the condition which stipulates that neither any of later scholars differs from the stand of the Imam due to the necessity or adjustment with the custom, nor does he proclaim the soundness of any other stand which is contrary to the Imam's (Hawwa \& Ali). 
4. If there is no opinion from the Imam about a case, and the case is reported in Zahir al-Riwayah, then the view of Abu Yusuf would be taken into account. If there is no stand available from him regarding the case then the opinion of Muhammad would be considered. If there is no stand from him, then the view of Zufar and Hasan ibn Ziyad would be taken into account. So, whenever the opinions of scholars of a certain period are not available then the stands of the comparatively senior scholars are to be considered. This sequence, however, would be accepted only from the mufti who is not capable of making the discretion (ijtihad). If he is capable of doing so, then he has the right to prefer any opinion which he feels is most applicable to the respective issue being relied on the evidence (Hawwa \& Ali).

5. If there is an opinion from an Imam about a case, and the case is not reported in Zahir al-Riwayah, but is in accordance with the principles and fundamentals of the School, it would be taken into consideration. It means that in any case the stand of the expert scholars (mashayikh) of the School would not be taken into account in the presence of the stand of any Imam of the School. This is subject to two conditions. First, it should be in accordance with the fundamental principles, and second, it should be ensured that any other stand which is contrary to this is not verified and validated by the expert scholars of the School (Hawwa \& Ali).

6. In a case where there is no opinion from any Imam, and the case is reported neither in Zahir alRiwayah nor in any other book, then the opinions of the earlier scholars are considered, if they all agree on one opinion. If they differ, then the stand of the majority would be accepted, such as the opinions endorsed by famous scholars of the Schools like Abu Hafs, Abu Ja'far, Abu al-Layth, alTahawi and so forth (Hawwa \& Ali).

7. In a case where there is no answer provided by the earlier scholars, then the mufti should think, deliberate, do ijtihad and then give judgment on the case, after trying the best he could. However, if the mufti is just an imitator then he should take the view of the one whom he deems more expert and more intellectual than his peers, and then annex the fatwa to him (Hawwa).

8. If there is a conflict between the analogy (qiyas) and the juristic preference (istihsan) in a case, then the juristic preference would be taken into consideration, with some exceptions (Hawwa).

Applying the abovementioned fundamental principles, and making an inductive reasoning into the preferred opinions of the Hanafi School, the following points have been derived:

A. Concerning the rituals (ibadat), the fatwa will be issued in accordance with the opinion of the Imam absolutely, as long as there is no second opinion from him which is contrary to the former one. For example, on the issue of the purity of used water, Abu Hanifah and Abu Yusuf opine that it is impure (najas) and hence impurity shall not be removed from it. Muhammad and another narration of the Imam opine that it is pure per se, but it is not a purifier, i.e. it does not purify others. However, impurity will be removed from it. Nevertheless, the School has issued a fatwa on its purity.

B. In a case pertinent to the judiciary, a fatwa will be issued in accordance with the stand of Abu Yusuf because he has more involvement and experience in this field.

C. With regard to the bequeathing of the relatives on the maternal side (zawil arham), a fatwa will be issued pursuant to the stand of Imam Muhammad. 
INTERNATIONAL JOURNAL OF ACADEMIC RESEARCH IN BUSINESS AND SOCIAL SCIENCES

Vol. 8, No. 9, Sept. 2018, E-ISSN: 2222-6990 @ 2018 HRMARS

D. In 17 cases a fatwa will be issued based on the opinion of Imam Zufar, where the later scholars of the School have preferred his stand (Hawwa \& Ali).

\section{Adopting the Less Preferred Opinion of the Hanafi School:}

As mentioned earlier that the committee of the Mejelle adopted some less preferred opinions of the Hanafi School, though the principle of this School is, as Ibn Abidin said that the preponderant opinion shall be taken into account, and it is not allowed to act according to less preferred opinion, since the less preferred stand against the preponderant is as if it does not exist (Ibn Abidin). However, in the Hanafi School it is not easy and facile to find out the preferred stand because it is surrounded by obscurity and confusion resulted from the conflict of opinions and arguments. This feeling is expressed by the committee of the compilation of 'Fatawa Hindiyyah', which comprises a good number of the great scholars of India, whereby in the introduction it says that, "the books and references available on this subject are not enough to cure the sick, and to quench someone's thirst because mostly these books encompass the narrations, arguments and opinions that are controversial and disputed in nature". The same is expressed in the report of the committee of the Mejelle whereby it says that, "undoubtedly knowledge of figh is a vast ocean without any coast. Deriving the ruling, and passing the judgment thereof requires deep and special knowledge and skill in fiqh, particularly with regard to the Hanafi School, since it has a huge number of scholars and jurists, and disagreement and discrepancy are also abundant in this School." Nevertheless, in order to make adjustment with the changes of times, places, and circumstances, the committee adopted the less preferred stands. Moreover, it is in accordance with the nature of the fundamentals (usul) of the Hanafi School, which provide a wide domain for the scholars in making decision and giving preponderance (Qubbaj).

For instance, in the case of selling the heap of corn (bay al-subrah), the Mejelle adopted the stand of the two disciples of Abu Hanfiah, that the sale is valid for the whole heap; whereas the Imam opine that it is valid only in approximately 700 grams (a mudd). The committee of the Mejelle followed the principle of tarjih in the Hanafi School which has been discussed above. The principle says that if the Imam is on one side and his two disciples are on the other side, and the discrepancy is due to the changes of times and places, according to an option the mufti will be given the right to make the decision pursuant to his own judgment. So, in order to make the issue easy and facile the Mejelle adopted the stand of two disciples (Qubbaj). Similarly, pursuant to this principle of tarjih, the Mejelle adopted the stand of two disciples in the duration of option by stipulation (Qubbaj). Furthermore, in the issue of revocation of the manufacturing contract (aqd al-istisna), the Mejelle adopted the stand of Abu Yusuf who opine that, in the manufacturing contract the buyer (mustasni) is not allowed to revoke the contract if he finds the item is manufactured according to the specifications stipulated upon the contract. However, Imam Abu Hanifah opines that in this case the buyer does not have the right to revoke the contract. Here the Mejelle applied the principle of tarjih which says that, although the case is reported in Zahir al-Riwayah, the experts of the School differ from this due to the necessity of the people for this contract, as well as due to the changes in custom and tradition (Qubbaj). Likewise, in the case of sale with condition (bay bi al-shart) the Mejelle adopted the stand of the Schools other than the Hanafi School (Qubbaj). 
INTERNATIONAL JOURNAL OF ACADEMIC RESEARCH IN BUSINESS AND SOCIAL SCIENCES

Vol. 8, No. 9, Sept. 2018, E-ISSN: 2222-6990 @ 2018 HRMARS

\section{Conclusion}

This research finds out that among the efforts made for the codification of Islamic law, the attempt of the Majallat al-Ahkam al-Adliyyah is comparatively more successful. The distinct feature of the Mejelle is that, pertaining to the compilation of fiqh, it explicitly distinguishes between the method of being the reference for knowledge and teaching and the reference for judiciary, in terms of sequence, numbering, simplicity of sentences, and limiting the different views of fuqaha in an issue to one opinion. This is a part of the requirements of legal drafting as the law is supposed to contain only the ruling that is compulsory to be implemented. The study concludes that the opinions which are adopted by the Mejelle from the Hanafi School are not necessarily always the preponderant stands of the School. Although generally the Mejelle adopted the views recorded in the books of Zahir al-Riwayah, in the cases that have more than one stand from Imam Abu Hanifah and his disciples, the Mejelle adopted the opinions that are consistent with public wellbeing as well as pursuant to the needs of the time. Hence, in some cases, the Mejelle did not take the stand of Zahir al-Riwayah, but took the view of others. Moreover, in few cases, the Mejelle adopted stands of the Schools other than the Hanafi School. Nevertheless, in the adoption process, the Mejelle complied with the principles of giving preponderance (qawa'id al-tarjih) of the Hanafi School of law.

The contribution and significance of this research can be addressed from the significance of the Mejelle per se. The Mejelle is a significant and important addition to the library of Islamic knowledge. Among the advantages of the Mejelle is that it has transformed the Islamic jurisprudence from its texts, elucidations, commentaries and divergent opinions to a single opinion. It has articulated the opinion on each case in a form of legal binding article. Moreover, it is a way to get rid of various fiqhi differences regarding the applications and it has determined the legal references for the judges while passing the judgment on various issues.

\section{References}

Aiyar, K,J. (2007). Judicial Dictionary, A Complete Law Lexicon. New Delhi: LexisNexis.

Ali, Muhammad Ibrahim Ahmad. (n.d.), al-Mazhab Inda al-Hanafiyyah. KSA: Ummul Qura University. Ashqar, U. S. (1982). Tarikh al-Fiqh al-Islami. Kuwait: Maktabat al-Falah.

Badawi, Yusuf Ahmad Muhammad. (2007). Madkhal al-Fiqh al-Islami wa Usuluhu. Amman: Dar alHamid.

Al-Bayhaqi, A. H. (2002). Dala'il al-Nubuwwah wa Ma'rifat Ahwal Sahib al-Shari'ah. Beirut: Dar alKutub al-Ilmiyyah.

Bugha, M. (2009). "Al-Taqnin fi Majallah al-Ahkam al-Adliyyah", Majallat Jamiah Dimashq al-Ulum allqtisadiyyah wa al-Qanuniyyah, vol.25, no.2, 743-772.

Cigdem,Y. D. R. (2005). Ahmed Cevdet Pasha (1823-1895): A Scholar and A Statesman. Islam Hukuku Arastimalan dergisi. Retrieved on December 27, 2013, http://en.wikipedia.org/wiki/Ahmed Cevdet Pasha.

Dar al-Mashriq. (2002). Al-Munjid fi al-A'lam. Beirut: al-Maktabat al-Sharqiyyah.

Fayyumi, A. M. (1323 AH). Al-Misbah al-Munir fi Gharib al-Sharh al-Kabir. Egypt: Maktabat al-Sayyid Muhammad Abd al-Wahid.

Fox, J. R. (1997). Dictionary of International and Comparative Law. New York: OCEANA Publications, INC. 
INTERNATIONAL JOURNAL OF ACADEMIC RESEARCH IN BUSINESS AND SOCIAL SCIENCES

Vol. 8, No. 9, Sept. 2018, E-ISSN: 2222-6990 (C) 2018 HRMARS

Hawwa, A. S. (2002). Al-Madkhal ila Mazhab al-Imam Abu Hanifah. Jeddah: Dar al-Aundulus alKhadra'

Husayni, M. (1993). Taj al-Arus min Jawahir al-Qamus. Kuwait: Ministry of Information.

Ibn Abidin, M. A. (n.d.). Majmu'at Rasa'il Ibn Abidin; al-Risalah al-Thaniyah Rasm al-Mufti. n.p., Alam al-Kutub.

Ibn Manzur, M. (1990). Lisan al-Arab. Beirut: Dar Sadir.

Khilayalah, Y. (2002). "Taqnin Ahkam al-Shari'ah al-Islamiyyah Bayna al-Nazariyyah wa al-Tatbiq," (Ph.D. Thesis, International Islamic University Islamabad).

Al-Majallah. (1302H). Beirut: al-Matba'at al-Adabiyyah.

Majma' al-Lughah al-Arabiyyah bi al-Qahirah. (2011). Al-Mu'jam al-Wasit. Egypt: Maktabat al-Shuruq al-Duwaliyyah.

Murad, A. F. (n. d.). Dictionary of Legal Terms in Four Languages. Egypt: n. p.

Qaradawi, Y. (1997). Madkhal li Dirasat al-Shari'ah al-Islamiyyah, Beirut: Mu'assasat al-Risalah.

Qattan, M. (1982). Tarikh al-Tashri' al-Islami. Beirut: Mu'assasat al-Risalah.

Qubbaj, S. M. (2008). Majallat al-Ahkam al-Adliyyah Masadiruha wa Atharuha fi Qawanin al-Shara al-Islami. Amman: Dar al-Fath.

Rahman, S. A. (1967). "Foreword" in The Mejelle; being an English Translation of Mejelleal-Ahkam alAdliyyah and A complete code on Islamic Civil Law, Lahore: Law Publishing Company.

Sajistani, S. I. (1997). Sunan Abi Daud. Beirut: Dar Ibn Hazm.

Shamela. Accessed on August 17, 2015. http://shamela.ws/index.php/author/424.

Shatari, A. S. (2007). Hukm Taqnin al-Shari'ah al-Islamiyyah. Riyadh: Dar al-Sami'i.

Sinha, H. M. \& Narula, D. P. (n.d.). Legal Dictionary. Delhi: Pioneer Publications.

Siraj, M. A. (1997). Al-Fiqh al-Islami Bayna al-Nazariyyah wa al-Tatbiq. Egypt: Alexandria University. 